\title{
"Educate that holy hatred": place, trauma and identity in the Irish nationalism of John Mitchel
}

\author{
G. Kearns \\ Department of Geography, University of Cambridge, Cambridge CB2 3EN, UK
}

\begin{abstract}
Many anti-colonial nationalisms incorporate a historical justification for independence. In the case of Irish nationalism, this historical argument has often drawn attention to traumatic historical events of conquest and famine. These traumas are blamed on the English colonisers. In this article, I explore some of the consequences of this particular way of tying together place and history in the service of nationalism. I argue that it can serve to deflect nationalists from detailed consideration of alternative futures towards a purely manichean critique of the past. (C) 2001 Elsevier Science Ltd. All rights reserved.
\end{abstract}

Keywords: Nationalism; John Mitchel; Ireland; Irish Famine; Colonialism; Trauma

\section{People, land and history in nationalist identities}

Among other things identities can interpellate (Althusser, 1971) people as members of a political community. They help define a group characterised by mutual obligations and rights. Identities help justify the limits of civil society. Nationalism is one form in which these identities are often expressed. The nation defines a people. When used to denote a political community, nationalism easily becomes a plea for statehood on the part of the people it defines. This conflation of nation and state was an axiom of the League of Nations (Heffernan, 1998; Shaw, 1998) and bedevils much theoretical work on nations and states. MacLaughlin (1986: 325) has criticised 'a state-centred political geography that seems almost impregnable.' There are a number of difficulties with assuming or asserting an identity between nation and state. Penrose (2001) argues that states should be defined by democratic rather than

E-mail address: gk202@hermes.cam.ac.uk (G. Kearns). 
by demotic principles. Lloyd (1999) finds a hidden anarchist tradition in some versions of Irish nationalism. Assuming too readily the identification of nation with state, can, for Penrose, leave minority rights ignored and, for Lloyd, can obscure the strong critique of statism offered from within the nationalist tradition. Nevertheless, it remains the case that, particularly in anticolonial struggles, independence is often asserted on the part of a distinct people, with a historical title to a defined territory. Independence involves economic and political sovereignty and thus aspires to statehood.

While the distinction between nations and states is poorly developed in the literature on nationalism, many make a related but different division between two sorts of nations. After Kohn (1965; Nairn, 1997 [1993]) scholars have distinguished between nations as groups defined by common descent, ethnic nations, and as groups defined by common citizenship rights, civic nations. Civic nations have been identified in western Europe, where absolutist states provided territorial containers for which democratic revolutions, from the seventeenth to the nineteenth centuries, defined new political communities. In eastern Europe, by contrast, nation-states occupied spaces broken off from larger territorial units as national identities were asserted against multinational empires during the late-nineteenth and first half of the twentieth centuries. The nationalist identities of Eastern Europe, then, affected to assume the preexistence of discrete ethnies rendered stateless by regional imperialisms. Before the court of world opinion ethnic nationalisms presented their credentials for statehood in broadly demotic terms.

National identities are built around three 'essentially contestable' (Collini, 1979: 15) terms, people, land and history. In the context of pleas for statehood, nationalism describes a people, a territory and a historical justification for the exclusive use of the territory by that people. The stories of ethnic primordialism that buttress these claims are often mythical or even fictional (Smith, 1986). Traditions are invented to diffuse and sustain the stories (Hobsbawm \& Ranger, 1983). Print culture may be a crucial prerequisite for the success of these demotic nationalisms (Anderson, 1983). Land has received less attention from scholars of nationalism but the territorial dimensions and integrity of the putative nation-state are central claims in most nationalisms (Smith and Williams, 1983). The stories that nationalists tell about land are many and various. They include broadly environmentalist arguments that connect a particular culture to the unique environment that produced it, primordial arguments about first occupance, blood-and-soil arguments about the sacrifices made to humanise a particular landscape, and anticolonial arguments about loss and dispossession. Nationalist histories, then, have to be stories not just about a people but also about their land. Historical geography, then, is an obvious form for nationalist ideology. These discourses are rarely self-critical but they are often effective (Dean, 1994).

Political and historical geographers (Johnston, Knight, \& Kofman, 1988; Driver, 1991) have recognised the geographical themes at the heart of nationalism and some 2\% of the articles published in Political Geography in the period 1982-96 concerned the concept of the nation-state (Waterman, 1998: 379). Some papers have paid close attention to the conception of the "people" in nationalist ideology but less to "history" or "land" (e.g. Penrose, 1994). Other geographers have brought in location by study- 
ing the symbolic places used in rituals of nationalist remembrance (Harvey, 1979; Kearns, 1993; Johnson, 1995; Atkinson \& Cosgrove, 1998). There has been some discussion of the continuing significance of territoriality in national identity (Newman \& Paasi, 1998) and of the way sites sacred to nationalism stake out a territorial claim (Azaryahu \& Kellerman, 1999).

\section{History, geography and the moral black-hole of trauma in Irish nationalism}

Geographers working on Ireland have produced some thoughtful analyses of the dilemmas of nationalism. Nash (1993) explores nationalist ideologies in which the west of Ireland was figured as female in ways that have a direct echo in the sexist nature of Eamon de Valera's (1882-1975) constitution of 1937 (Hanafin, 1997). The roads not taken in Ireland included co-operative alternatives to competitive capitalism, which might yet yield inspiration for more pluralist conceptions of nationhood (Nash, 1998). Poole (1997) has noted the difficulties that ethnic division poses for the cultivation of civic nationalism in the Republic of Ireland and in a related if exaggerated way for Northern Ireland. Graham (1997: 209) worries that the institutionalised divisions between unionism and nationalism make it impossible to forge the 'integrative place consciousness' out of which political consensus might emerge.

Ethnicity and citizenship attempt uneasy congress in Irish identities. Britain and Ireland are anomalous in terms of Kohn's political geography. Like the other empires of Eastern Europe, the United Kingdom and the British Empire in fact constituted an imperial space from which various nation-states seceded. First, the Anglo elite of one of its colonies broke away to form the federated United States and then the subject people of its oldest colony rebelled into the independent Irish Free State bequeathing uneasy independence from Britain to twenty six counties and contested integration with Britain to six Irish counties. Anderson and Goodman (1998: 7) note that Northern Ireland is the residue of a series of failed attempts at state-building by British and Irish nationalists alike. They see 'just a chance' that Ireland 'might pioneer a transnational settlement process' whereby Britain, both Ireland and Europe can distribute different powers to various scales in ways that build confidence through a system of power-sharing and extra-territorial checks and balances. This is what Kearney (1997) refers to as a 'postnationalist' polity. MacLaughlin (1997: 182) has suggested that the modernisation of the economy of the Republic of Ireland within Europe has transformed social attitudes. This has produced an embarrassment with nationalism that bids fair to enshrine historical 'revisionism' as a state ideology while depoliticising many formerly anxious subjects such as emigration. Others see this consolidation of revisionism as a significant defeat for Republicanism (Power, 1996). Johnson (1999) documents an official approach to Irish history in the Republic that, in its attention to tableaus and to decontextualised themes, all but empties history of process, of the trajectory that bears so much judgement and blame. Yet this official approach may not have achieved much purchase with the public, at least in the Republic (Canavan, 2000).

Revisionism in Irish history sets itself against what it connotes as nationalist pieties 
(compare Boyce \& O’Day, 1996 with Brady, 1994 and Eagleton, 1998). Some nationalist versions of history adopt a manichean vision in which virtuous Ireland is subject to unrelenting abuse from perfidious Albion over the entire period from the Norman invasion of 1169 until the glorious rebellion of 1916. The British garrison in Ireland, some believe, was staffed by a Protestant élite that featured as the Ascendancy in Dublin and as the plantation Presbyterians of Ulster. Against this, revisionists contest the simplicity of the claim that colonialism explains Ireland's past. The Famine is contextualised to the point where British agency and thus responsibility all but disappears and the rebels of 1916 are given such feet of clay that no good at all could be expected from their 'romantic' sacrifice. Eagleton very properly asserts that, whereas each side has much to learn from the other, a nuanced debate is difficult to secure while the political situation remains so fraught. There appears to be too much at stake for revisionists to appear to condone terrorism or for nationalists to appear to condone partition.

Of course, the nationalist historiography is often a good deal subtler than revisionists perceive and some revisionists acknowledge the trauma and injustice of Irish history to a greater extent than nationalists have given them credit for doing. Walker (1996), for example, directs a revisionist gaze towards unionist historiography. To contextualise historical narratives is not necessarily to reject them. Leerssen (1996) argues that the priority of history within the Irish Republican political imagination springs from the sense of grievance over the Act of Union (1800) being passed without the promised act of Catholic Emancipation. From this sense of betrayal, suggests Leerssen, many Irish republicans concluded that justice could never be expected from a British government and that all previous history of the relations between the islands of Britain and Ireland bore this out. What hangs over the historiographical debate, though, is not just modern politics, but also the dilemmas of dealing with national identities organised around extreme situations. There is, I think a moral black hole to trauma sucking in nuance and leaving only extremism beyond its pull. Irish history lends itself to apocalypse because Irish identities must negotiate the Famine, the mass emigration and the partition. Cleary (2000) argues that it is only with its passing that a trauma explicitly impels itself upon a consciousness that returns obsessively to unfinished business. A first step towards understanding and living with a traumatic history is to acknowledge it and its effects. In the case of Irish nationalism, the case of John Mitchel (1815-75) is a good place to start.

This paper sketches Mitchel's biography, considers his reliability as a historian of the Famine, it surveys his historical method, it describes his model of insurrection and it concludes by considering his legacy. This case-study sheds light upon one important strand in Irish nationalism. It also helps us to address some of the ambivalences in the theories of nation and state. Mitchel's description of the Irish as enslaved made independence and citizenship essential for basic self-respect. The status of citizen required an independent polity for one to be a citizen of. The willing slave might be happy but would always be contemptible. For Mitchel, at least, independence was more important for what it said about human dignity than as a way of defending ethnic distinctiveness. A colonised people is made distinctive politically, regardless of whether it feels unified in any cultural sense. In this sense the national- 
ism of resistance, so characteristic of colonial and imperial contexts, must (Kohn, 1965) ever have a civic before an ethnic dimension (Kearns, 2001). Furthermore, an anti-colonial nationalism of resistance that seeks citizenship as redress for exploitation and denigration will almost certainly (Lloyd, 1987) posit statehood as its goal. Finally, postcolonial identities that are shaped around trauma may have a legacy of manichean vision that denies internal divisions in the name of a unity that was imposed by the colonial power.

\section{John Mitchel, the famine and exile}

In 1848, a song called 'Michells [sic] Address' was doing the rounds in London. Its first verse tells Mitchel's sad tale: 'I am a bold true Irishman, | John Mitchell is my name, | To join my brave countrymen | From Newry first I came, | I struggled hard both night and day | To free my native land, | For which I was transported, As you may understand' (Anon, 1848: 11. 1-8). Mitchel was born in Dungiven, about 30 miles east of Londonderry, in 1815 (Dillon, 1888a). In 1823 the family moved to Newry. His father was a Presbyterian minister, a Remonstrant who left the Presbyterian Synod of Ulster in 1829 when attempts were made to curb freedom of expression in the cause of stamping out Unitarianism. John Mitchel was first intended for the ministry himself but growing agnosticism took him so far from his father's faith that, after a somewhat undistinguished career at Trinity College Dublin, he settled upon the Law. Although he lived in Newry his work took him often to Dublin where he became increasingly interested in Daniel O'Connell's campaign for the repeal of the constitutional Union between England and Ireland.

O'Connell had campaigned successfully that Catholics might sit in the House of Commons. Known as the Liberator on the strength of this Catholic Emancipation Act of 1829, O'Connell was having difficulty recruiting Protestants or the middle classes to the cause of Repeal. In 1841, Thomas Davis (1814-45) (Molony, 1995), a Protestant journalist living in Dublin, joined O'Connell's movement bringing with him a number of young professionals, some of them Catholics but many of them Protestants, friends from his student days at Trinity. The group around Davis was known as Young Ireland. They believed that a union of all classes was possible in the cause of Repeal. Throughout the summer of 1843 O'Connell thrilled crowds measured in the tens and even hundreds of thousands with his talk of defying the British army and frightening the British government into the sort of concessions they had been forced to concede in 1829. In 1844, Mitchel began attending meetings of O'Connell's Repeal Association. In that same year, the government called O'Connell's bluff sending him to prison for threatening armed conspiracy because a mass meeting which, in accordance with government instructions he had called off, had been promoted by insurgents in uniform. In 1845, Mitchel (1846) wrote a biography of a famous Irish resistance leader, Hugh O'Neill, and was then taken on as staff writer for the influential Young Ireland newspaper, the Nation. Once out of prison, O'Connell tried to drive all hint of insurrection out of his Repeal Association. O'Connell required all members of the Repeal Association to disavow the use of violence 
under all and any circumstances. In this way he hoped to put the Repeal Association beyond state interference but he was also delighted that in the process he drove Young Ireland out into a new organisation called the Irish Confederation. Davis told Mitchel that the Irish people now more than ever needed to school themselves in military arts. At this very moment, Young Ireland lost its unity with Davis' early death and Ireland at large lost its means of living with the failure of the potato crop.

The Famine began with the blighting of the potato crop in 1845 (Kinealy, 1994). About half the crop failed, a crop that was the basic foodstuff of about two-fifths of the Irish population. In 1846 almost all the potatoes were lost to blight. In 1847 only about one-ninth of the normal acreage was sown, the poor having few seed potatoes left. Complete blight returned in 1848. In 1845, Ireland may have had a population of about nine million. Of these, probably more than a million died from starvation or famine-related infectious diseases, such as typhus (Ó’Gráda, 1999: 85). If to these are added the 'averted births' of the dead mothers (Mokyr, 1983), the direct and indirect effect of mortality on the population total was almost certainly to depress it by at least one-and-a-quarter million. In the period 1845-55 some oneand-a-half million Irish people emigrated (Ó’Gráda, 1989: 48). A population that had been growing quickly at first and then more moderately over the first four decades of the century lost $30 \%$ of its total to the Famine and stood at 6.5 million at the 1851 census.

Mitchel now became the main writer at the Nation and quickly moved to a more martial tone. In the face of first desperate poverty and soon actual starvation, Mitchel began to advocate James Fintan Lalor's (1807-49) policy (Buckley, 1990) of taking the land of Ireland back from the landlords so that the people might reallocate it in a way that enabled them to feed themselves. The Irish harvest should not be sent to England to pay rents to absentee landlords. It should be held in Ireland, if necessary at the point of a gun, in order that Irish people did not starve. Mitchel was driven out of the Confederation for a radical tone that seemed to imperil the dream of an all-class alliance against the English. In advocating armed resistance, Mitchel fell foul of a new law passed in the wake of the February 1848 revolution in France. This made it an offence to speak against the integrity of the British empire. Mitchel was convicted of such a treason-felony and was transported on May 27, 1848. He spent almost all the rest of his life in exile, first in Australia and then shuttling between the United States and France. In exile, he pondered long on the implications of the English government presiding over famine in one part of its claimed kingdom and of the failure of his own arrest to ignite a revolution. In the last year of his life, 1875 , he returned to Ireland in defiance of his banishment and contested a parliamentary seat at Tipperary. He told his electors that he favoured 'the sovereign independence of Ireland' (Dillon, 1888b: 289). He had, he said, no intention of ever going to a British parliament since begging freedom from the tyrant was manifestly pointless.

Mitchel's Jail Journal; or Five Years in British Prisons (1996 [1854]) became a classic of the nationalist struggle. In 1914 Patrick Pearse (1879-1916) said it was 'one of the holy books of Ireland: the last gospel of the New Testament of Irish nationality' (Foster, 1997: 524). Mitchel came to exemplify insurrectionary nationalism. On those occasions, when William Butler Yeats (1865-1939) (1990 [1939]: III: 
11. 1-6) wanted to make the case for violence in politics, it was to Mitchel that he turned:

You that Mitchel's prayer have heard

'Send us war in our time, O Lord!'

Know that when all words are said

And a man is fighting mad,

Something drops from eyes long blind,

He completes his partial mind [...].

This wedding of nationalism to violence was explicitly gendered. Arthur Griffith (1871-1922) (1913: xv) wrote of Mitchel as 'the manliest man who summoned her [Ireland] to action in generations.' Frank McCourt (1996: 231) recalls that when in bed recovering from typhoid his 'Dad lets me read his favorite book, John Mitchel's Jail Journal, which is all about a great Irish rebel the English condemned to exile in Van Diemen's land in Australia'.

\section{Accounting for the famine}

In terms of the national trilogy of land, people and history, Mitchel placed greatest emphasis on the last. Land was the cause for which people should fight. The people were defined by sentimental allegiance. History taught that the land had been stolen from the people. History taught that the Irish economy was crippled by British colonial rule. The Famine showed that under this colonial administration, the Irish could not even feed themselves. The British wanted Ireland as a food-supplying colony with fewer mouths at home to consume the food intended for industrial Britain. The potato blight was sent by god, but the famine and the emigration were engineered by Britain. Mitchel's aim was to keep this record before the Irish people so that he might, as he wrote in 1848, 'educate that holy hatred' (quoted in Chuto, 1995: 180). I want to trace some of the implications of building identities around trauma in this way. I will suggest: that hatred takes shame as its familiar; that shame and hatred stoke national assertion to the point where fidelity to the cause incites accusations of betrayal against those who differ on tactics; that violence itself becomes a salving method or ethic rather than a mere tactic; that the national community is conceived of in mystical terms rather than as a context-constrained and variegated political grouping; and, finally, that this mystical entity can be called into existence by a blood sacrifice that atones for the shame of the nation even as it justifies the hatred nurtured among the elect. First, however, I want to acknowledge that there is much to commend in Mitchel's analysis of the Famine.

The case against Mitchel as historian seems obvious to many. Edwards and Williams (1956: vii) consider that Mitchel wrote in an exaggerated way about the famine'. Their criticisms are two-fold. The first is that Mitchel over-emphasises the political context of the famine at the expense of its political-economic setting. They sought to pit James Connolly (1868-1916) against Mitchel, which is odd given the 
reliance of both Connolly and Mitchel on Lalor for their distinctive class-based approach. Indeed to quote Connolly against Mitchel in the following manner - No man who accepts capitalist society and the laws thereof can logically find fault with the statesman of England for their acts in that awful period' (quoted in Connolly: viii) — is ironic given Mitchel's own 'Apology' for the British government, claiming that it did no more and no less than was needed to maintain the Empire - 'I hope the impartial reader will acknowledge that those coroner's juries which afterwards sitting upon starved corpses, found verdicts of "wilful murder against John Russell, commonly called Lord John Russell", were altogether in the wrong; the verdict ought to have been, justifiable homicide' (1905 [1860]: 17). Of course, Connolly did expect his readers to find fault with capitalism and Mitchel expected them to reject imperialism. But both grounded their understanding of these faults in the class structure of Irish agriculture. The distribution of rural property allowed landlords and, in turn, the British state to exploit producers. In the second place, Edwards and Williams argue that modern historians who agree with Mitchel simply fail to understand the ideological blinkers that made it impossible for contemporary statesmen to do other than they did. Extensive state intervention, they suggested, lay some long way in the future. The problem with this complaint is that Mitchel was not judging British ministers with the benefit of hindsight in this manner. He was objecting to their departing from established methods of dealing with famines; in particular, the sort of bans on the export of food that contemporary Belgium imposed. In the context of the 1840s, it was the do-nothing approach that was radical and innovative and it required, as Gray (1995) shows, the ideological support of the certainties of both classical political economy and providential protestantism. It made economic sense and it served god's ends to let nature and thus the market take its course. Mitchel's argument is simply stated. Given a choice between economic efficiency and Irish lives, the British government chose economic efficiency. Given a choice between doing god's will by moralising the Irish poor and, on the other hand, simply keeping the immoral poor alive, the British government chose morality and mortality.

Graham Davis attempts to relegate the demographic significance of the Famine, and argues that crossings of the Irish Sea were nowhere near as bad as painted, except in winter or summer (Davis, 1991: 46). There was, in any case argues Davis, emigration before and after the Famine (p. 21). As for a generalised famine, people at the time, argues Davis (p. 30) would have had no more than local knowledge: '[a]ll that people could have known during the famine period was based on local incidents and drawn from anecdotal experience'. Davis is convinced that the modernisation of agriculture polarised the class structure and ejected surplus labourers in a more or less automatic fashion. Davis (1997: 20) believes that Mitchel ignored 'the complexity of the ideological debate conducted in Britain and Ireland'. Davis describes the soup-kitchen policy as 'a triumph of pragmatism over dogma' (p. 31) suggesting it kept thousands alive. The special pleading here is quite naked.

O'Farrell (1982) argues that Mitchel's success was essentially an aesthetic one. With this famine, the enormity of the context overwhelmed all attempts to give it meaning through the explication of individual lives. Not literature but history was best placed to deal with such a mass event. Instead of the madness and desperation 
of the event, Mitchel recovered a single narrative thread in blaming it all on the English government. This argument invites us to contextualise Mitchel's historical writing and see how Mitchel worked to produce meaning in his text. The remainder of this paper attempts to do this but we can only do so if we also acknowledge that the Famine was a traumatic, unique and extreme event. The 1.5 million who emigrated in the ten years following 1845 (Ó Gráda, 1989: 46) was more than double the number who had left in the previous thirty (Ó Gráda, 1999: 228). In July 1847 at least one-third of the Irish population was being fed at soup kitchens (Ó Gráda, 1999: 73) before the policy but not the need was ended. The rate of mortality exceeded that of any other European famine of the nineteenth century; probably all European eighteenth-century famines, with the possible exception of Ireland in 1741; and, setting aside the 1918-22 famine in the Soviet Union, of any famine anywhere since (Ó Gráda, 1999: 5). Emigration and low fertility continued after the famine and the population of Ireland taken as a whole declined in each subsequent decade of the nineteenth century. Alone among European countries it still has a lower population than in 1845. Without Mitchel, demography alone would give the Famine a singular status.

Mitchel produced reasonable mortality estimates. In the semi-official Thom's Irish Almanac, the population decline between 1841 and 1851 was put down to emigration rather than mortality and the lesson drawn related to wanderlust rather than starvation: 'unless the emigration be soon arrested, the country will be deserted by its original population' (Thom's, 1853: 252). Emigration from Ireland was estimated at 1.3 million and the population decline at 1.5 million. Mitchel's estimates were better than this. He pointed out that the Famine was confined to the second half of the decade. Thus he raised the population by half a million to account for the growth 1841-5. He halved the emigration to cover only the period 1846-51. The population decline would thus be about 2 million and the relevant emigration about 0.6 million. His mortality estimate (Mitchel, 1899 [1867]: II 243) of about 1.5 million is much more robust than the almanac's 0.25 million.

Turning to Mitchel's account of government policy, it is hard to avoid Donnelly's (1996: 61) conclusion that: 'a million people should not have died in the backyard of what was then the world's richest nation, and that since a million did perish while two million more fled, this must have been because the political leaders of that nation and the organs of its public opinion had at bottom very ambivalent feelings about the social and economic consequences of mass eviction, mass death, and mass starvation'. In some ways, his detractors concede as much, with Davis (1997: 19) asking: '[i]f the Famine had struck Cornwall instead of Cork would appropriate measures have been taken to prevent starvation and death?' At this time, of course, Ireland was as much a part of Great Britain as was Cornwall. In round figures, the British government spent about seven million pounds in famine relief over the period 184553 , even if much of it was originally considered as loans. More than this was raised in poor rates in Ireland itself (Donnelly, 1989). Furthermore, the 'loan' to Ireland was to be repaid by a tax upon Ireland alone. As the Irish M.P. Isaac Butt (181379) argued at the time, this was little less than a repudiation of the Act of Union (Gray, 1997: 107). 
The British did not want to kill the Irish or let them die just because they were Irish. However, British policy was directed by people who could contemplate largescale starvation in service of a greater good. Benjamin Jowett (1817-93) confessed a 'certain horror of political economists' ever since he had heard Nassau Senior (1790-1864) explain 'that he feared the famine of 1848 in Ireland would not kill more than a million people, and that would scarcely be enough to do much good' (Woodham-Smith, 1962; 375-6). Certainly, Senior and others saw the famine as providential and they saw Ireland as a laboratory where the principles of political economy could be taken to their limit. Senior confided to Alexis de Tocqueville (1805-59) that: '[e]xperiments are made in that country on so large a scale, and pushed to their extreme consequences with such a disregard to the sufferings which they inflict, that they give us results as precious as those of Majendie' (Ó'Gráda, 1993: 128). The costs were to be borne by the Irish yet the benefit was to the Union. Senior thought the sacrifice was worth it for it would advance 'all that makes England worth living in' (loc.cit.). The famine was a god-given opportunity to restructure the Irish economy so that it might play its proper role within the imperial system. Britain needed food from Ireland and was easily persuaded that under a system of comparative advantage the Irish should specialise in meeting that need, a need that was best served by a labour-efficient agriculture, certainly not potatoes, perhaps cereals or livestock. Lord Carlisle (1802-64), the Lord Lieutenant for Ireland (1855-8, 185964), explained these colonial realities to an Irish audience. Climate and the market dictated that Ireland should be a pastoral economy: '[c]orn, you well know, can be brought from one country to another, from a great distance, at rather small freight. It is not so with cattle - hence the great hives of industry in England and Scotland [...] have a constant dependence on Ireland for an abundant supply of meat' (Brown, 1972: 221). Ireland needed a decrease in its population so that England and Scotland could get an increase in their food. An Englishman's meat was an Irishman's poison. Mitchel described as colonial and murderous, a policy that contemplated Irish deaths to serve the greater good of an agriculture meeting English needs. It seems entirely appropriate to set famine policy in this colonial context and to accept that Irish life weighed quite lightly in the scales of imperial policy. In the remainder of this paper, I want to explore some of the implications of rooting national identities in such a trauma, a tactic adopted in many anti-colonial struggles.

\section{From conquest to famine}

For Mitchel, the central issue in Irish history was the incomplete conquest of Ireland by Britain. This was a colonial and not a religious tyranny. It concerned land rather than confession. The famine exemplified this and gave the anticolonial struggle its life-and-death character. However, this extremism had certain rhetorical consequences that issued in a failure to think explicitly about the shape of an independent Ireland. It would be enough simply to achieve independence. Yet the original critique of imperialism suggested a whole series of principles as the basis for constructing an independent Ireland. These principles were sidelined in the mortal struggle to prize English fingers from the Irish windpipe. 
The tension between, on one hand, the enumeration of the detailed injustices of British rule and, on the other hand, the identification of the British as the source of all evil runs through all Mitchel's writings. The Famine devalued the former and promoted the latter. The shift in emphasis from conquest to famine deferred a series of implicit questions. While independence was argued for on the basis of specific injustices, there was a clear suggestion that Ireland free would be Ireland just. There was an invitation to a rights-based discourse about the new independent Ireland. Survival trumps all, however, and the grounding of independence arguments in the trauma of the Famine beggared few questions about Ireland-free beyond the need to throw out the British. As Young Ireland moved from Davis and Lalor to Mitchel, it moved from questions of citizenship towards issues of sovereignty alone.

From Davis and Lalor, Mitchel learned a set of pleas for Irish independence that rested upon justice arguments. From Davis Mitchel learned arguments about the political basis of citizenship, from Lalor economic arguments about the propertied basis of the social contract. Mitchel accepted Davis' claim that time conferred nationality. For settlers, familiarity bred citizenship. This enabled him to discount historical arguments about the source of property titles and offer a purely synchronic argument about exploitation. The Protestants who were given the stolen lands of Ulster became Irish with time: '[...] the very undertakers that planted Ulster grew racy of the soil; and their children's children became, thank God! not only Irish, but united Irish — became "Eighty-two" Volunteers — anti-Union patriots — in every struggle of Irish nationhood against English domination' (Mitchel, 1846: vii). Mitchel here describes how time in Ireland produces patriotism despite the original basis of people's title to the land. On these grounds the Ulster plantation Presbyterians became as Irish as the Catholics they displaced as witnessed by the role of Presbyterians in defending the Irish Parliament in 1798, the resistance of the United Irishmen, the name he gave to his journal of 1848. Mitchel avowed fealty to a Protestant genealogy of Irish patriotism quarrelling with those such as Thomas Burke who would define Irish as Catholic: '[a]s a non-Catholic, then, I am ruled out of court, as well as Grattan and Tone and O'Brien. We are not quite Irish under this rule' (Mitchel, 1873a: 9). For Mitchel, the Irish landscape was a palimpsest of colonisation and resistance. Describing a trip to Belfast from Dublin, he made sure to remind his readers of the historic sites they passed over, near or within sight of: '[...] hard by the fatal field of the Boyne Water; near also, but not within sight of Mellifont Abbey - the Appomotax of Hugh O'Neill, where he delivered up his sword to Mountjoy - [...] through Newry, the stronghold of Marshal Bagnal, in Queen Elizabeth's time' and then to Belfast where they could see 'the healthy hills of Antrim, with the cliffs of Cave Hill and Mac Art's Fort, where, on a certain day, Wolfe Tone and his friends registered a vow - a vow which they are still keeping, though in their graves, for their spirit is not yet buried' (Mitchel, 1945: 78).

Following Lalor, Mitchel argued that the Conquest of Ireland meant that the social contract was maintained by force in defiance of the wishes and needs of the Irish people. In 1848 he told the readers of his United Irishman that ' $[\mathrm{t}]$ he Irish people have a just and indefeasible right to this island, and to all the moral and material wealth and resources therefore, to possess and govern the same for their own use, 
maintenance, comfort, and honour, as a distinct sovereign State' (Ó Cathaoir, 1978: 18). Any social contract sustained by force must in justice yield before more basic needs and wishes. To farmers during the Famine, he proclaimed '[i]f it needs all your crops to keep you alive, you will be justified in refusing and resisting payment of any rent, tribute, rates, or taxes whatever. This is the true doctrine of Political Economy' (O'Hegarty, 1917: 84). To restructure Irish agriculture to serve Irish needs probably required a revolution for the landlords would never cede their privileges in any other way. As Mitchel explained in a letter to a friend who quailed before the prospect of an Irish Terror: '[...] I have small faith in peaceful regeneration where there is such a diseased body politic. Instruct and convert landlords, and that otherwise than by terror and imminent peril - Think over it again, and don't grow euphemistical' (Dillon, 1888a: 92). In supporting a Coercion Act of 1847 that sought to disarm Irish rebels, the landlords showed their true colours in 'their coward fear of an outraged and plundered people' (Mitchel, 1873b: 250). The British allowed Irish landlords to exploit Irish peasants because Irish food found its way to British tables but now the British needed more food and Irish depopulation followed as night day for '[i]t needed too much of the produce of the island to feed such a mob of Celts; and improved systems of tillage would give more corn and cattle to English markets, more money to Irish landlords' (Mitchel, 1996: 14). When the Anglo-Irish Ascendancy imagined it could pursue distinct interests in conflict with English interests, it was swiftly disabused. In the late seventeenth century the English parliament banned the export of Irish woollen cloths to anywhere but England and Wales and then only under such high tariffs that they were quite uncompetitive. Mitchel read this as a clear instruction to the Protestant Ascendancy that they were to serve British interests first (Mitchel, 1899: I 28-9). Sectarian divisions were fomented by the British 'with the express purpose of preventing an union of Irishmen of all creeds a thing which is felt to be incompatible with British Government in Ireland' (Mitchell, 1899: II, 304).

For Mitchel, to be complicit in depopulation through preventable famine was to be guilty of nothing less than murder. In this sense, there was an 'unnatural and fatal sort of connection between Irish landlords and Irish tenants' (Mitchel, 1899: II 226) which led the landlords to see benefit in the deaths of their own tenants. Following Lalor, Mitchel saw the Famine as dissolving the social contract in Ireland: "when hundreds of thousands of people were lying down and perishing in the midst of abundance and superabundance which their own hands had created, [...] [t]hat form of Society was not only a failure, but an intolerable oppression; and cried aloud to be cut up by the roots and swept away' (Mitchel, 1873b: 253-4). Like Lalor, Mitchel did not see property as an absolute right: '[p]roperty is an institution of society [...] but when matters come to that utterly intolerable condition they have long been in Ireland, society itself stands dissolved - a fortiori - property is forfeited [..]' (Mitchel, 1996: 79).

There is a clear tension here between the utilitarian argument that democracy and peasant proprietorship happen to provide greater food security for all, and a rightsbased argument that a just society requires enfranchised peasants. Mitchel's discussion of the French Revolution served the utilitarian argument. After the Jacobin 
Terror in France, 'the class of nobles was destroyed, the great estates of the proprietors were cut up and allotted to small farmers, and France has been a rich independent and prosperous country every since' (Mitchel, 1917: 15). To the Protestant farmers of Ulster, Mitchel insisted that there was in Ireland no adequate defence of tenant right and living standards to be found in 'the repeal of the Catholic Emancipation Act, nor yet the repeal of the Union Act by itself [...]. Nothing will cure it save the total overthrow of the aristocratic system of government and the establishment of the People's inalienable Sovereignty' (Mitchel, 1917: 9). There were, however, equally strong arguments from first principles. Mitchel was sure that ' $[\mathrm{t}]$ he time is long gone when Jehovah anointed kings. [...] There is no divine right now but in The Sovereign People' (Mitchel, 1917: 26). The right of the Irish to control their own resources meant taking the land back from landlords be they English, Irish, Protestant or Catholic. Repeal of the Union, therefore, was "essentially not only a national movement, but also — why not admit it? - a class movement' (Mitchel, 1917: 18). The Famine tilted the balance towards utilitarian arguments. To keep people alive, colonialism and landlordism must be ended whatever the cost and notwithstanding the lack of any detailed plan for what would replace them.

Mitchel put the Famine rather than the Conquest at the heart of his history. He almost decontextualised the traumatic event as an act of pure malevolence: 'Mitchel possessed hates of British things before the Great Famine; but as the hunger progressed and men and women died as loose gangling bags of bones, he became possessed by hate' (O'Neill, 1945: 44). In October 1845, Mitchel wrote in the Nation about the dangers presented by the failure of the potato crop in Ireland. In November he noted that hunger had ever been a potent provocation of revolution (Dillon, 1888b: 101). By February 1846, the inaction of the British government was driving him to despair: 'Oh, Heavens! do these men know what potatoes are? — what famishing men are? Have they any conception even yet that there may soon be certain millions of human beings in Ireland having nothing to eat?' (Dillon, 1888b: 104). By the end of the year, the famine was real enough and he wrote to his schoolfriend John Martin (1812-75) that '[t]his is a horrible subject, this famine, and the matters pertaining to it. Did you read the terrible accounts from Skibbereen?' (Dillon, 1888b: 142). In February 1847 Mitchel went to Galway to assist Thomas Francis Meagher (182367 ) in his unsuccessful attempt to dislodge a Government placeman in a by-election. The trip west from Dublin took him into the famine districts of Leinster. He was shocked. On reflection, he assimilated the experience to his manichean vision: 'I saw Trevelyan's claw in the vitals of those children: his red tape would draw them to death: in his Government laboratory he had prepared for them the typhus poison' (Mitchel, 1873b: 247). At the time, he quite lost his bearings in a landscape that no longer showed signs of life or history: "what reeking breath of hell is this oppressing the air, heavier and more loathsome than the smell of death arising from the fresh carnage of the battlefield. [...] [W]e are here in the midst of these Golgothas that border our island with a ring of death from Cork Harbour all round to Lough Foyle' (O'Neill, 1945: 44). In this account published at the height of the Famine in June 1847, Mitchel described villages in the west where: '[t]here is a horrible silence; grass grows before the doors; we fear to look into any door, though they are all 
open or off the hinges; for we fear to see yellow chapless skeletons grinning there; but our footfalls rouse two lean dogs, that run from us with doleful howling, and we know by the felon-gleam in the wolfish eyes how they have lived after their masters died (ibid., 45). As Mitchel wrote of Meagher, '[s]cenes like these it was that at last maddened my poor friend and many other men to the pitch of desperation, and made them fling themselves blindly, with naked hands upon the armed giants of English tyranny' (Mitchel, 1945: 74).

If Mitchel was somewhat deranged by the Famine, exile confirmed his loss of bearings: '[a]n exile in my circumstances is a branch cut from its tree; it is dead, and has but an affectation of life. Ever since that banishment from my own country, [...] I am conscious of a certain vagabond, or even half-savage propensity' (Dillon, 1888b: 117). Mitchel could not be restored to the full compass of his faculties until he was himself returned to an independent Ireland. Conquest, famine and exile were successive stages in Mitchel's alienation from a coherent national subjectivity. Morash (1995: 127, 63) writes of James Clarence Mangan (1803-49) registering the Famine as an apocalyptic collapse of narrative structures and of Mitchel seeing Ireland tipped into a continuous and tragic present awaiting that revolutionary act of national redemption which alone can return it to the van of history. By suspending Irish history at the Famine, Mitchel also replicated the experience of those many other emigrants who saw Irish history as unfinished business to which they would lend a hand when the time was right (Morash, 1995: 61). Lloyd (1987: 51) remarks that this close association between personal and national restoration is intrinsic to romantic nationalism.

\section{History, critique and revolution}

The relationship between historical evolution and personal development was particularly close in much of the literature of the period. The individual was realised in seeking reconciliation to the spirit of the age. The realist novel told the tale of an individual's passage from singularity or particularity to social integration. The anomalous individual learns to be reconciled with society and its projects, whether, as mostly for men, through labour or, as mostly for women, through love and marriage' (Lloyd, 1993: 134). The nationalist version of this transcendence lay in the assertion of a harmony between the progressive spirit of the age and the local customs of a place which allowed an individual to cultivate their sense of self-worth in being true to both. For certain persons this was more difficult than for others. Eagleton has described the difficulty that the Anglo-Irish élite faced in being true both to the democratic spirit of the age and to their own fear of their disenfranchised Catholic and dispossessed peasant neighbours. This contradiction induced a sense of stasis among the middle classes and those who wrote for them. William Carleton (17941869), the son of a Catholic tenant farmer, converted to Protestantism and supplied stories of the countryside for literary journals. Eagleton suggests that Carleton could see no evolutionary shape to embrace in Irish history. His novels, therefore, create a split between individuals and their social context. The story-line and the morality 
spring from interpersonal intrigues while the social context lacks a developmental schema being treated in a static, almost naturalistic way (Eagleton, 1995: 213).

There are, it seems, blocked choices. Believing in the progressive business of wider democracy was difficult for those whose sense of well-being rested upon the very privilege that wider democracy would displace. Conversely, the dispossessed and disenfranchised likewise faced problems in seeing their path to autonomous subjectivity as signposted by the spirits of age and place. The hegemonic culture was English and it presented something like the English constitution, the Anglo-Saxon race, bourgeois property rights, a Protestant religion, patriarchy and the heterosexual family as the universal ideal. Deviation from this was presented as a lack and, in metaphorical terms, any one dimension of absence could be used to describe any other (Kearns, 1997). Rooted in violence and then defended as common sense, the English view of the Irish figured them as deviant or deficient not different or oppressed. Kiberd writes of Ireland as re-imagined after each re-conquest by the English: 'Ireland was soon patented as not-England, a place whose peoples were, in many important ways, the very antithesis of their new rulers from overseas' (Kiberd, 1995: 9). Kiberd suggests that the English projected onto the Irish the characteristics which were suppressed in their own cultivation of autonomous bourgeois subjectivity: '[t]hus, if John Bull was industrious and reliable, Paddy was held to be indolent and contrary; if the former was mature and rational, the latter must be unstable and emotional; if the English were adult and manly, the Irish must be childish and feminine' (Kiberd, 1995: 30). Because their place was configured as so out-of-kilter with the spirit of the age, Irish nationalists could either change their place or challenge the hegemonic view of progressive social evolution. Many promoted both revolution and critique.

History was intrinsic to the two related appeals providing justification and promise for the former and figuring as a field of contested meanings for the latter. Yet this is an unstable compound for two main reasons. In the first place, to critique the meanings expressed in hegemonic histories denied nationalists any easy appeal to those same meanings when outlining the coming utopia of national independence. This was particularly difficult for nationalists such as Charles Gavan Duffy (18161903) who longed for a sort of bourgeois democracy very like the English. Lloyd (1987: 77) argues that 'Irish nationalism, in its early theory as in its later practices, has always sought to be an instrument of bourgeois hegemony'. Eagleton notes that many Irish writers addressed a metropolitan English audience in whose eyes they wished to be judged respectable, if not acceptable. Noting that standard English is often used in Carleton's novels where the appeal is to the mind of the reader, and dialect where the appeal is to the heart, Eagleton suggests that the casting of generalisations in standard or even bureaucratic English effectively distances the reader from the experiences about which the generalisation is offered. He gives a very striking example from 'Carleton, who when writing of famine in The Black Prophet [1847] speaks of "that languid look of care and depression, which any diminution in the natural quantity of food for any length of time uniformly impresses on the countenance" (Eagleton, 1995: 210). The critique of hegemonic evolutionary history prejudiced any attempt to imagine a purely bourgeois revolution. 
The second tension between critique and revolution lies in the universalism of the first and the particularism of the nationalist version of the second. The attack on the English self-image as enlightened and progressive concentrated upon English cant. The English were hypocrites because their actions were at variance with their espoused values. The true realisation of the ideals of liberty, equality and fraternity required the expulsion of the canting English tyrants. This is the universal dimension of Davis' version of citizenship and Lalor's argument for land reform. Yet, all too often, the nationalist appeal goes further than this, asserting that it is government interference of all kinds, and not just the colonial kind, that distorts civil society and that the national revolution is to be made, not in the name of universal ideals, but in the name of certain specific national virtues. In this respect, Eagleton's remarks about Arthur Griffith apply equally to John Mitchel: '[i]n Romantic nationalism, a particularism of people and place begins to oust a universalism of human rights, so that the revolution, when it arrives, is lacking in much ontological dimension beyond God and nation. This style of thought divorces the libertarian impulse of the Enlightenment from its liberalism, embracing the former while sceptical of the latter' (Eagleton, 1995: 235).

The third reason why critique and revolution formed an unstable compound lies in the role that hate played in explanation and empowerment. The history of the Conquest provided an account of a historical process. It was a story of cause and effect in which some of the causes and context were purely contingent. Things could have turned out differently on various occasions, were it not for the treason of some Irish, the good fortune of the English in securing international alliances that allowed them to turn their armies exclusively upon Ireland, and in some cases were it not for the weather driving the friendly forces of Spain or France away from Irish shores. The Irish need simply wait. England's misfortune was ever Ireland's opportunity. Next time, perhaps, the English would not be so lucky. Alongside this understanding of history as contingent process, there was another very different view in which the Conquest, and even more the Famine, featured as acts of such pure malevolence, with such apocalyptic consequences that Irish misfortune became almost a force of nature or whim of god. This millenarian view threatened to decontextualise Irish history. The revolution came to be seen as an act of pure will justified by an act of pure evil. Thomas Carlyle's (1795-1881) celebration of violent resistance, antagonism towards the materialist philosophy of the age and account of the French Revolution as an act of spontaneous combustion informed Mitchel's political philosophy on precisely this point. This set a premium upon asserting a unity of interest among the Irish people, the pursuit of adherents rather than allies. Making a revolution involved little more than stoking the fires of hatred to the point where resistance spread like wildfire among the masses of the people. The people would be thrilled not drilled into rebellion. History, then, was a contested field where colonisers and colonised struggled for the right to give meaning. It was also the bedrock of revolution as both justification and utopian projection. In basing his nationalism on history, John Mitchel exemplifies the difficulties in making these necessary connections between critique and utopia. 


\section{Be our watchword henceforth Hatred!}

In his History of Ireland, Mitchel (1899: I 193) cited with relish the confession of the leader of the 1798 rebellion, Theobald Wolfe Tone (1763-98), that '[m]y object was to secure the independence of my country under any form of government, to which I was led by a hatred of England, so deeply rooted in my nature, that it was rather an instinct than a principle'. Their colleague Duffy (1887: 209) claimed that while 'Davis loved Ireland, Mitchel hated England'. Indeed, Duffy claimed further that hatred of England was all that Mitchel had by way of reasoned argument in favour of his revolutionary appeal, eschewing the cultivation of nationalist sentiment so important to Davis or the insurrectionary preparations demanded by the Clubs. Mitchel's biographer, Dillon (1888a: x), wrote that '[f]rom the opening of the year 1848 down to the day of his death, John Mitchel's mind was dominated by a ruling passion. That ruling passion was hatred of the British Imperial systemhatred of the system in all its workings, but, above all, hatred of the system as it worked in Ireland'. In a remarkable letter of November 1857 to a close friend, Mitchel himself reflected that he was driven by a hatred arising out of his shame at the oppression of Ireland rather than by a positive love of his country. He found on reflection that what stung most was his "scornful impatience at the thought that I had the misfortune, I and my children, to be born in a country which suffered itself to be oppressed and humiliated by another' (Dillon, 1888b: 104). With refreshing candour, Mitchel described a plausible set of links between shame and hate. He also explains how it felt to be the subaltern subject of a hegemonic discourse. The British word held sway in the world by virtue of the attraction people feel for wealth and power. In this sense, it is only when things are reported in the British press that they are seen to be true. Mitchel even suggested with heavy irony that nothing had truly happened until the news of it had been reflected back from London (Morash, 1995: 69).

This 'bitter and irreconcilable enemy to the British government' (Hodges, 1848: 19 ), as he styled himself in a speech in Limerick shortly before his arrest for treasonfelony, cheered every reverse of the British Empire wheresoever it occurred. He was probably the author of the article on the similarities between India and Ireland which claimed that: "[t]ruly has England been the curse of mankind - the withering upas tree, which has blighted all upon which its has cast its shadow - the swoln [sic] monster, which has drawn the life-blood from every victim upon which it has been able to fasten its vampire fangs' (Anon, 1847: 1015b). In his journal, United Irishman, he reported news from the British Empire in sections entitled, 'The Enemy in Africa', 'The Enemy in Asia', and so on (O'Hegarty, 1917: 80). On 1 June 1848 Mitchel left Ireland from Spike Island in Cork harbour aboard a convict ship. Even on a hulk at Bermuda, Mitchel could enjoy minor British embarrassments. The other prisoners objected to the privileges accorded to Mitchel as a gentleman rather than a common convict. Mitchel liked this for it might lead the other prisoners towards 'a wholesome hatred of those damnable "institutions" which make so much of gentlemanhood and so little of manhood - to wit, the glorious British Constitution in Church and State' (Mitchel, 1996: 77). In April 1849 with his asthma threatening 
his life, the British decided to send him to the Cape of Good Hope to continue his sentence of fourteen-years' transportation. The colonists of the Cape, would not receive the shipload of convicts, refusing to allow their district to become another penal colony. Local traders boycotted the British navy under the pressure of a boycott from their neighbours. For five months, the ship remained at anchor before it sailed to Van Diemen's Land (Tasmania) instead. Mitchel was left helpless with laughter at this affront to the power of the British Empire (Mitchel, 1996: 176).

In August 1853, Mitchel escaped from Tasmania and arrived in San Francisco in October. Through journalism and books, Mitchel continued to preach the same manichean gospel. On every occasion when Britain seemed set to become embroiled in war, Mitchel hoped to prize an expeditionary force for the liberation of Ireland out of Britain's enemies. Then, the unfinished business of 1798 and of 1848 might be taken up once again. At first he had high hopes of the United States. In exile in Australia he dreamed he might soon 'be in America, directing the filibustering and crusading energies of that republic to the regeneration of the human race - sending forth armies of fiery Yankees to set Poland on her feet, to set Kossuth high in Buda Pesth, to shut up the Emperor in Ham once more - to erect provisional governments in Dublin Castle, Buckingham Palace, Vienna, Berlin, and Milan [...]' (Mitchel, 1996: 264). He hoped that the interference of the British in the commercial affairs of the United States during the Civil War might precipitate conflict. He negotiated with the French and with the Russians on separate occasions and had no luck in either case. He wanted arms and men, not cash. At the very end of his life, he returned to Ireland and stood in a by-election in Tipperary. Mitchel told the electors he was in favour of 'the sovereign independence of Ireland' and that he would 'seek the total overthrow of the Established Church' (Dillon, 1888b: 289). Mitchel's antipathy to all things English was consistent and intense. Introducing his two-volume History of Ireland, he warned that 'while England lives and flourishes, Ireland must die a daily death [...]' (Mitchel, 1899: I viii).

Mitchel's sanguinary rhetoric and the imperial scale of the struggle he was describing frightened some of his colleagues. The first article in which Mitchel developed this global vision was in the Nation of 28 March 1846, when he praised the resistance shown by Indian Sikhs to British imperialism. Mitchel went on to suggest that 'the blow which is to destroy the English Empire in the East is likely to be struck "nearer home" (Shannon-Mangan, 1996: 315). Mitchel's gospel of hate radicalised the rhetoric of the Nation.

For Lloyd (1993: 73), the distinction between cultural and militant nationalism rests in large part in their contrasting foundational myths. In these terms, Lloyd compares William Butler Yeats with Patrick Pearse. Yeats wanted to found the nation in a cultural unity to be forged through poetic exploration of Ireland's past. Pearse urged revolution as a blood-sacrifice founding the nation through an act of violence that could be commemorated. The martyr and not the poet was presented as the exemplary nationalist subjectivity. Martyrdom is an act that takes an event outside history and treats it as a pure point of origin. In some ways, a more relevant distinction in the case of Young Ireland is the distinction between violence as a tactic and violence as an ethic. It was tactical violence that informed Davis' efforts, along with 
John Dillon (1816-66) and Michael Doheny (1805-62), to turn O'Connell's mass meetings of 1843 into regimented rehearsals for the revolutionary army they wished to train. Of the meeting at Cashel, Doheny (1914: 21) reported that: '[e]ach parish came in procession, headed by a band and commanded by some local leader; and those who took part in the public procession marched in excellent order for upwards of eight miles'. The reversal at Clontarf persuaded Davis that O'Connell could not force concessions from the British simply by the appearance of main force. The threat needed greater credibility and may even need to be made good in deed. When Davis met Mitchel for the last time, shortly before his death in October 1845, Mitchel was given a copy of the Artillerist's Manual with the observation that Irish people now needed to turn their attention to works such as this (Newsinger, 1980: 185). In the United Irishman, Mitchel published extracts from these and other works along with 'ferocious, if vague, directions for street fighting in Dublin' (Woodham-Smith, 1962: 336). The opposition to Mitchel within Young Ireland was, for many parties, a matter of tactics not principle. Doheny and Meagher were later to prove they had no fear of insurrection but in January 1848 they criticised Mitchel. Dohney said that '[w]hen a man talks of arming, he should begin to act; and if he begins to act without weighing his means, and assuring himself of a probability, at least, of success, he must be surely mad' (Duffy, 1887: 184). Meagher appealed in despair: '[w]as an insurrection practicable? Prove it to him it was, and he would vote for it that night'.

For Duffy, '[t]he root of Mitchel's error was that he pushed to its extreme limits a theory of Carlyle's - that a revolution is necessarily as spontaneous and as ungovernable as a movement of nature' (Duffy, 1887: 197). Duffy, who had little taste for insurrection under any circumstances, averred that revolutions did not 'spring like thunder out of a sunny sky, unexpected and unpredicted, [they] were [...] the result of a secret conspiracy'. In other ways, Duffy enjoyed Carlyle's rhetoric and, in Young Ireland, he described evenings when he and his friends would read aloud from Carlyle's works. Indeed, the suppers were 'dubbed "tea and Thomas", (Davis, 1987: 32). Even late in his life, in 1892, Duffy had Yeats and other dinner guests entertained to a reading of Carlyle's Heroes and Hero-Worship (Foster, 1997: 121). When Mitchel wrote a biography of Hugh O'Neill (c.1540-1616), an Irish earl who came to lead the fight against Elizabeth I, Davis complained of the Carlyeisms in the work. Mitchel conceded to Duffy: '[...] I confess that I am inclined to ultra vehemence in speaking of that time [...]' (Duffy, 1884: 266). Mitchel idolised Carlyle. In his life he spent but one night in London, in May 1846, and he spent that evening visiting Carlyle in Chelsea (Dillon, 1888a: 110). Later that year, Carlyle made a tour of Ireland and visited Mitchel in Dublin (Dillon, 1888a: 122). When Mitchel was arrested in 1848 he corresponded with Carlyle confiding a fear of being locked up with low brigands. Carlyle wrote to the Lord Lieutenant of Ireland, Clarendon, entreating that Mitchel be treated as a gentleman and not as a common criminal, a request that was, in large part, acceded to (O'Conner, 1985: 77). Like Carlyle, Mitchel viewed violence as a justifiable means of exerting a will to power. Mitchel saw insurrectionary violence as a system of morality in itself, an exemplar that revealed the true nature of the oppressor and the true interest of the oppressed. While marooned aboard the convict ship off the Cape of Good Hope, he heard of the 
defeat of the Hungarian Revolution but he was not despondent over the plight of the Hungarian people: '[t]he blood of men fighting for freedom is never shed in vain - the earth will not cover it: - from the ground it cries aloud, and the avenger knoweth his day and his hour. [...] It is through this bloody travail and by virtue of this baptism of fire, and only so, that nations ever spring forth, great, generous and free (Mitchel, 1996: 192-3). This is militant nationalism in exactly the sense evoked by Pearse. Mitchel wanted to goad the British state into attacking him with the sort of unfair violence that would give such offense to his fellow countrymen that their shame could be swift turned to anger and revolt. Only free persons had political rights. No person with self-respect could tolerate such a condition.

The lead article in the first issue of United Irishman (12 February 1848) was entitled 'To the Right Honourable the Earl of Clarendon, Englishman: calling himself her Majesty's Lord Lieutenant General and General Governor of Ireland'. Daring Clarendon to have him arrested for sedition, Mitchel vowed that ' $[\mathrm{t}]$ hat holy Hatred of foreign domination which nerved our noble predecessors fifty years ago still lives, thank God! And glows as fierce and hot as ever. To educate that holy Hatred, to make it know itself, and avow itself, and at last fill itself full, I hereby devote the columns of the United Irishman' (Chuto, 1995: 180). Mitchel also addressed Clarendon as 'Her Majesty's Executioner General and General Butcher in Ireland' and as the 'High Commissioner of Spies and General Suborner in Ireland' (WoodhamSmith, 1962: 339). Mitchel was tried for treason-felony; a new offence created some few days before his arrest. It made it illegal to encourage anyone to act to break up the United Kingdom; there need be no actual plot. Mitchel was tried before a blatantly rigged and exclusively Protestant jury, convicted and sentenced to fourteen years' transportation. Mitchel said that this proved that English law was unsafe in Ireland and that English rule relied upon naked oppression. It also showed that the English did not treat Irish Catholics as citizens in their own land, Catholics were no better than 'slaves' (Mitchel, 1996: 25). Mitchel, in fact, approved of slavery outside Ireland, thinking it appropriate for African people, and a far gentler system than English laissez-faire in Ireland. Looking upon what he took to be 'fat and merry' slaves in a Brazilian port, Pernambuco, Mitchel reflected upon the Irish 'slaves' he had left behind: '[t]he poor slaves I have been accustomed to see are not only of no value, but their owners will go to heavy expense to get rid of them - not imported slaves, but slaves for export - slaves with a glorious Constitution, slaves with a Palladium - a Habeas Corpus to be suspended, and a trial by jury whereby they may have the comfort of being rooted out of house and home, transported, and hanged at the pleasure of the "upper classes"" (Mitchel, 1996: 150). The repeated invocation of Irish slavery was an attempt to shame his compatriots into action.

Adverting to his own martyrdom also served to educate that holy hatred. Mitchel's speech from the dock after he had been convicted was typical. He admitted that his own insolence in the face of insuperable odds might seem foolhardy but he recalled the Roman citizen who thrust his hand into the fire, asking which of his friends would take up his defiance: '[t]he Roman who saw his hand burning to ashes before the tyrant, promised that three hundred should follow out his enterprise. Can I not promise for one, for two, for three?' (Dillon, 1888a: 244). His friends in the court- 
room quickly too up the cry swearing defiance and devotion. Mary Anne Kelly (1830-1910), writing as 'Eva' in the Nation, echoed the appeal in a poem: 'For one - for two — for three - | Aye! Hundreds, thousands, see! | For vengeance and for thee | To the last!' (Keneally, 1998: 151). Mitchel (1996: 315) had faith that such a gesture might be all that was required to set the Irish people alight: 'I believe in moral and spiritual electricity; I believe that a spark, caught at some happy moment, may give life to masses of comatose humanity'. But the Confederates had decided that the Dublin Clubs were not ready to attempt a rescue. Meagher had explained this to Mitchel, asking that Mitchel address the Clubs in a letter approving the decision (O'Conner, 1985: 81). Mitchel refused. The decision, he thought, 'was wrong; and, as I firmly believe, fatal'; the failure to resist an expulsion for such a crime, after such a trial, would mean that 'the British Government could have little to fear from [the Dublin people's] resentment or their patriotism afterwards' (Mitchel, 1996: 20). Even with hindsight, Mitchel saw that moment as pregnant with opportunity. In 1857, he described himself as a man 'whose whole life and energy and passion converged themselves once to one focus, and were then dissipated' (Dillon, 1888b: 104). Mitchel's courtroom question, then, was a reproach and while Meagher, and other Confederates, 'restrained the Clubs', they 'promised action in the harvest (a promise they afterwards fulfilled to the best of their ability)'. But it was a promise that bespoke no further calculation. They had pledged to use violence. Violence had moved from tactic to ethic. The rebels must emulate 'the felon-gleam in the wolfish eyes' of the famine dogs. Lalor said they must 'unmuzzle the wolf dog' of agrarian insurrection (Woodham-Smith, 1962: 333). 'Maddened' by the famine, they needed to give full rein to their own 'half-savage propensity'. Doheny, Thomas D'Arcy McGee (1825-68), Meagher and others went away from Dublin to organise the revolution, but in July 1848, unlike in January, they were eager to throw in their lot with a revolt they were sure would fail. The difference was not only due to the intensity of the Famine but also to the betrayal and unredeemed blood-sacrifice of Mitchel having left Ireland surrounded by an angry Dublin crowd which was being restrained by the leading Confederates.

\section{The music of her woe}

There is a tension between violence as a tactic and violence as an ethic. There is a tension between history seen as a sequence of contingent causes and effects and history seen as the expression of some basic essence. Mitchel's historical writings, conflating his own martyrdom with Ireland's subjugation, frequently cross these lines. In doing so, they place the colonial conflict in an imaginary space beyond secular calculation. This eschatological style drew upon Jonathan Swift's (16671745) sarcastic attacks on the lack of democracy in Ireland; upon William Cobbett's vitriolic exposure of the corruption of capitalist Britain, the 'thing'; upon Carlyle's spitting rejection of modern cant; and upon the biblical record of God testing, punishing and redeeming the Chosen People. Mitchel was brought up a Unitarian but became rather agnostic. Yet his vision of trial, redemption and justice remained 
biblical in its rhetoric and even in its confidence that no great wrong could last for all time; the colonial tide would turn. In rehearsing the wrongs to Ireland, Mitchel's history not only stoked the fires of hatred but also placed England's crime before the eyes of Irish people as an affront to nature and God.

There are a number of problems here for the Irish nationalist. To recruit God to one's side, even implicitly, was to raise a standard that might rally sectarian passions as easily as forge nationalist unity. Such language is almost wholly absent from Davis' writings where the invocation of a more secular mutuality of citizenship is reinforced by a self-effacing refusal to put himself forward as exemplification of the national cause. Yeats (1970: 16) thought that Davis' self-restraint came from a dislike of the sectarian consequences of O'Connell's rhetoric: '[O'Connell's] violent nature, his invective, his unscrupulousness, are the chief cause of our social and political divisions'. The 'temper' of Mitchel's books had, according to Yeats, an 'almost wholly mischievous' effect in ensuring that 'there has not arisen in Irish public life a tradition of restraint and generosity' (Yeats, 1970: 19-20). Raising the Irish cause to a biblical power left little space for cultivating civility in place of sectarian mistrust. Mitchel would not let go of the penal days.

It was for this apocalyptic tone and for his unswerving separatism that his writings were so loved by rebels of 1916. Writing shortly before the Easter Rising, Pearse (1976a: 93) claimed that 'Mitchel was of the stuff of which the great prophets and ecstatics have been made. He did really hold converse with God; he did really deliver God's word to man, delivered it fiery-tongued.' Constance Markievicz (1868-1927), in similar terms, called Mitchel 'one of the Divine Ancestors of Easter Week' (Sebestyen, 1986: 226) and told her sister that 'Mitchel's rhetoric is like a bible to patriots and is quoted up and down the land' (Sebestyen, 1986: 276). I have tried, in this paper, to explain the emotional appeal of Mitchel as well as some of the consequences for the way independence was imagined. However, between Mitchel and Pearse there was not only the sort of 'apostolic succession' described by Pearse (1976b: 29), there was also a political and economic history that made Mitchel attractive to certain groups in certain places at certain times. After the unsuccessful insurrections of 1848 and 1849 most of the leaders of revolutionary republicanism were exiled to Australia although many later found their way to the United States. There, they nursed their nationalist aspirations and found enthusiastic audiences among Irish emigrants who blamed the British for their own exile from their native land. It was among the 'alienated sons of commercial prosperity' (Comerford, 1985: 35 ) that this new diasporic nationalism found its leaders but it was among a much wider group of political and, more especially, economic exiles that it found its followers. It was in Mitchel's writings that it found its gospel. Back in Ireland, however, things took a somewhat different course.

In the immediate post-Famine period, insurrection was in the descendent. Many who remained in the countryside had benefited from the mass emigration by gaining tenancies of larger, consolidated farms thus barring 'any possibility of a fundamentally social or political revolution in nineteenth-century Ireland' (MacLaughlin, 1994: 6). Reformist pressures there took the utilitarian dimension of Lalor's arguments and emphasised tenure reform as a means to give farmers fair security to stimulate 
investment. But this 'indigenous model' (Bull, 1996: 11) of landlord-tenant relations also recalled Lalor's emphasis on the injustice of Irish property relations as springing from the injustice of conquest. From 1879-82 this agitation took the form of a Land War that aimed at making rent rises and farm consolidation impossible. Some argue that this movement radicalised the countryside along economic lines pitching large against small farmers (Bew, 1978) while others suggest that in the heartland of the movement, the West of Ireland, the division between Catholic tenants and AngloIrish Protestant landlords gave the movement a clear sectarian dimension (Bull, 1996). Clarke (1979) is impressed with the extent to which the rural social structure was being simplified under commercial pressures with a stronger associational culture being fostered among both large and small farmers equally interested, as they were, in the export economy. Because it mobilised the countryside to demand revision of property relations in ways inimical to free-trade Britain, the movement certainly took on a nationalist hue. Charles Parnell (1846-91) promised that land reform would 'undo the work of the Famine' (Bew, 1978: 82) but in seeking support among Irish-Americans he was driven to radicalise his programme beyond mere fixity of tenure to the demand for owner-occupation with the creation of a peasant class. By the early twentieth century, however, significant land reform had been achieved and the nationalist momentum lost.

The insurrectionary tradition was nurtured among the Irish-Americans of the Fenian Brotherhood who promoted rebellion in Ireland resulting in the unsuccessful rising of 1867 . Thereafter, and continuing to draw inspiration from Mitchel's writings, the Irish Republic Brotherhood persisted as a secret, oath-bound society in the United States awaiting an opportunity to foment revolution in Ireland. In 1907 Tom Clarke (1857-1916) returned from political exile in the United States to animate the secret organisation in Ireland in anticipation of the opportunity that would be afforded by the European war to which he perceived Britain to be racing. The conspiracy remained a limited one until 1913 when the very real prospect of Home Rule for Ireland prodded Ulster Unionists to vow armed resistance to rule from Dublin. The British government stood by as gun running into the north of Ireland produced an effective army of Ulster Volunteers. At this point, with the die loaded so heavily against any constitutional settlement, many Irish nationalists, including Pearse, joined their own Irish Volunteers and some, including Pearse, became party to Clarke's conspiracy. It was to proselytise for revolution that Pearse turned to Mitchel and in early 1916 published a series of pamphlets in which he lauded Mitchel's fiery nationalism. Preparing for revolution left little space for preparing for independence and, despite the best efforts of James Connolly (1858-1916), the necessary debate about the shape of a future independent Ireland was rather muted.

The idealism of Mitchel's nationalism deferred serious consideration of what the new order might look like. By mere negation independence would rescue individual and people. People, land and history were brought together in a critique of colonialism and landlordism. That critique, however, did not ground a detailed debate about the purpose of independence. The Famine inflated the rhetoric of the nationalist struggle taking the wind out of the sails of the rights-based arguments that were earlier appealed to in attacking colonialism and landlordism. Hatred and shame fed 
on each other as Mitchel showed Irish people how they must look through English eyes-creatures not even worth keeping alive. Violence becomes an act of self-respect. The unity of the nation is given by its common enemy. Struggle against drowns out the appeal of struggle for. These are some of the prices that are paid for basing identities on trauma. The historical geography of identity formation returns us to the context in which these identity claims are made, claims that seek to cut loose from that context altogether.

\section{Acknowledgements}

They may not all agree with my interpretation here but I would like to thank the following for their advice: Brendan Bradshaw, Anne Buttimer, Andy Charlesworth, Jim Duncan, Nancy Duncan, Millie Glennon, Mike Heffernan, Phil Howell, Niall Johnson, Dave Lambert, Paul Laxton, Denis Linehan, Hannah Moore, Joy Porter, Simon Reid-Henry, Ray Ryan, Willie Smyth, Gerard Toal, Kevin Whelan, Hannah Weston. I am also grateful for the helpful comments of anonymous referees.

\section{References}

Althusser, A. (1971). Ideology and ideological statue apparatuses (notes towards an investigation). In L. Althusser (Ed.), Lenin and philosophy (pp. 127-186). London: New Left Books.

Anon. (1847). India and Ireland, Nation, 24 December, 1015b-d.

Anon. (1848). Mitchells address. E. Hodges, London. British Library HS.74.1250 [vol.2, piece 54].

Anderson, B. (1983). Imagined communities: reflections on the origin and spread of nationalism. London: Verso.

Anderson, J., \& Goodman, J. (1998). Nationalisms and transnationalism: failures and emancipation. In: J. Anderson \& J. Goodman (Eds.), Dis/agreeing Ireland: contexts, obstacles and hopes (pp. 6-26). London: Pluto Press.

Atkinson, D., \& Cosgrove, D. (1998). Urban rhetoric and embodied identities: city, nation and empire at the Vittorio Emanuele II monument in Rome, 1870-1945. Annals of the Association of American Geographers, 88, 28-49.

Azayahu, M., \& Kellerman, A. (1999). Symbolic places of national history and revival: a study in Zionist mythical geography. Transactions of the Institute of British Geographers N.S., 24, 109-123.

Bew, P. (1978). Land and the National Question in Ireland, 1858-82. Dublin: Gill and Macmillan.

Boyce, D. G., \& O'Day, A. (Eds.). (1996). The making of modern Irish history: revisionism and the revisionist controversy. London: Routledge.

Brady, C. (1994). Constructive and instrumental: the dilemmas of Ireland's first 'new historians'. In: C. Brady (Ed.), Interpreting Irish history: the debate on historical revisionism (pp. 1-31). Dublin: Irish Academic Press.

Brown, M. (1972). The politics of Irish literature: from Thomas Davis to W. B. Yeats. London: George Allen and Unwin.

Buckley, D. N. (1990). James Fintan Lalor: radical. Cork: Cork University Press.

Bull, P. (1996). Land, politics and nationalism: a study of the Irish land question. Dublin: Gill and Macmillan.

Canavan, T. (2000). The profession of history: the public and the past. In R. Ryan (Ed.), Writing in the Irish Republic: literature, culture, politics 1949-1999 (pp. 225-241). London: Macmillan.

Chuto, J. (1995). James Clarence Mangan and the beauty of hate. Éire-Ireland, 30, 173-181. 
Collini, S. (1979). Liberalism and sociology: L. T. Hobhouse and political argument in England, 18801914. Cambridge: Cambridge University Press.

Clarke, S. (1979). Social origins of the Irish land war. Princeton, NJ: Princeton University Press.

Cleary, J. (2000). Modernization and aesthetic ideology in contemporary Irish culture. In: R. Ryan (Ed.), Writing in the Irish republic: literature, culture, politics 1949-1999 (pp. 105-129). London: Macmillan.

Comerford, R. V. (1985). The Fenians in context: Irish politics and society 1848-52. Dublin: Wolfound Press.

Davis, G. (1991). The Irish in Britain 1815-1914. Dublin: Macmillan.

Davis, G. (1997). The historiography of the Irish Famine. In: P. O'Sullivan (Ed.), The meaning of the famine (pp. 15-39). Leicester: Leicester University Press.

Davis, R. (1987). The young Ireland movement. Dublin: Gill and Macmillan.

Dean, M. (1994). Critical and effective histories: Foucault's methods and historical sociology. London: Routledge.

Dillon, W. (1888a). In The life of John Mitchel, (Vol. I). London: Kegan Paul, Trench Co.

Dillon, W. (1888b). In The life of John Mitchel, (Vol. II). London: Kegan Paul, Trench \& Co.

Doheny, M. (1914). The felon's track, or the history of attempted outbreak in Ireland, embracing the leading events in the Irish struggle from the year 1843 to the close of 1848. Dublin: M. H. Gill and Son.

Donnelly, J. S. (1989). The administration of relief, 1847-51. In: W. E. Vaughan (Ed.), A new history of Ireland. V. Ireland under the Union, I. 18-1-70 (316-331). Oxford: Clarendon Press.

Donnelly, J. S. (1996). The construction of the memory of the famine in Ireland and the Irish diaspora. Éire-Ireland, 31, 26-61.

Duffy, C. G. (1884). Young Ireland. Part I. A fragment of Irish history 1840-1845. Dublin: M. H. Gill and Son.

Duffy, C. G. (1887). Young Ireland. Part II. Or four years of Irish history, 1845-1849. Dublin: M. H. Gill and Son.

Eagleton, T. (1995). Heathcliff and the Great Hunger: studies in Irish culture. London: Verso.

Eagleton, T. (1998). Revisionism revisited. In: Eagleton, T. (Ed.), Crazy John and the Bishop and other essays on Irish culture (308-327). Cork: Cork University Press.

Edwards, R. D., \& Williams T. D. (1956). Foreword. In: R. D. Edwards, \& T. D. Williams (Eds.), The great famine: studies in Irish history, 1845-52 (vii-xvi). Dublin: Browne and Nolan.

Foster, R. F. (1997). W.B. Yeats: A life. I: The apprentice mage, 1865-1914. Oxford: Oxford University Press.

Graham, B. (1997). The imagining of place: representation and identity in contemporary Ireland. In: B. Graham (Ed.), In search of Ireland (pp. 192-212). London: Routledge.

Gray, P. (1995). The triumph of dogma: ideology and famine relief. History Ireland, 3, $26-34$.

Gray, P. (1997). Famine relief policy in comparative perspective: Ireland, Scotland and Northwestern Europe, 1845-1849. Éire-Ireland, 32, 86-108.

Hanafin, P. (1997). Defying the female: the Irish constitutional text as phallocentric manifesto. Textual Practice, 11, 249-273.

Griffith, A. (1913). Introduction. In: J. Mitchel (Ed.), Jail Journal . Original edition with a continuation of the journal in New York and Paris (pp. ix-xvi). Dublin: Gill and Son.

Harvey, D. (1979). Monument and myth: the building of the Basilica of the Sacred Heart. Annals of the Association of American Geographers, 69, 362-381.

Heffernan, M. (1998). The meaning of Europe: geography and geopolitics. London: Arnold.

Hobsbawm, E. J., \& Ranger, T. (Eds.). (1983). The invention of tradition. Cambridge: Cambridge University Press.

Hodges, J. G. (1848). Report of the trial of John Mitchel for felony, before the Right Honourable Baron Lefroy, and the Right Hon. Justice Moore, at Commission Court, Dublin, May, 1848. Dublin: Alexander Thom.

Johnson, N. (1995). Cast in stone: monuments, geography and nationalism. Environment and Planning D. Society and Space, 13, 51-65.

Johnson, N. (1999). Historical geographies of the present. In: B. Graham \& C. Nash (Eds.), Modern historical geographies (pp. 251-272). Harlow: Prentice Hall. 
Johnston, R. J., Knight, D. B., \& Kofman, E. (Eds.). (1988). National self-determination and political geography. London: Croom Helm.

Kearney, R. (1997). Postnationalist Ireland: politics, culture, philosophy. London: Routledge.

Kearns, G. (1993). The city as spectacle: Paris and the bicentenary of the French Revolution. In: G. Kearns \& C. Philo (Eds.), Selling places: the city as cultural capital, past and present (pp. 49-103). Oxford: Pergamon.

Kearns, G. (1997). The imperial subject: geography and travel writing in the work of Mary Kingsley and Halford Mackinder. Transactions of the Institute of British Geographers, N.S., 22, 450-472.

Kearns, G. (2001). Time and some citizenship: nationalism and Thomas Davis, Bullán: An Irish Studies Journal (in press).

Keneally, T. (1998). The Great Shame: a story of the Irish in the Old World and the New. London: Chatto and Windus.

Kiberd, D. (1995). Inventing Ireland: the literature of the modern nation. London: Jonathan Cape.

Kinealy, C. (1994). The Great Calamity: the Irish famine 1845-52. Dublin: Gill and Macmillan.

Kohn, H. (1965). Nationalism: its meaning and history. Princeton NJ: Van Nostrand.

Leerssen, J. (1996). Remembrance and imagination: patterns in the historical and literary representation of Ireland in the nineteenth century. Cork: Cork University Press.

Lloyd, D. (1987). Nationalism and minor literature: James Clarence Mangan and the emergence of Irish cultural nationalism. Berkeley: University of California Press.

Lloyd, D. (1993). Anomalous states: Irish writing and the postcolonial moment. Dublin: Lilliput Press.

Lloyd, D. (1999). Nationalisms against the state. In: D. Lloyd, Ireland after history (pp. 19-36). Cork: Cork University Press.

MacLaughlin, J. (1986). The political geography of 'nation-building' and nationalism in social sciences: structural vs. dialectical accounts. Political Geography Quarterly, 5, 299-329.

MacLaughlin, J. (1994). Ireland: The Emigrant Nursery and the World Economy. Cork: Cork University Press.

MacLaughlin, J. (1997). The devaluation of 'nation' as 'home' and the de-politicisation of recent Irish emigration. In: J. MacLaughlin (Ed.), Location and dislocation in contemporary Irish society: emigration and Irish identities (pp. 179-208). Cork: Cork University Press.

McCourt, F. (1996). Angela's Ashes: A Memoir of a Childhood. London: Harper Collins.

Mitchel, J. (1846). The Life and Times of Aodh O'Neill, Prince of Ulster, Called by the English, Hugh, Earl of Tyrone; With Some Account of his Predecessors, Con, Shane and Tirlough. Dublin: James Duffy.

Mitchel, J. (1873). The crusade of the period. In: J. Mitchel, The crusade of the period; and last conquest of Ireland (perhaps) (pp. 1-92). New York: Lynch, Cole and Meehan.

Mitchel, J. (1873 [1860]). The last conquest of Ireland (perhaps). In: J. Mitchel, The crusade of the period; and last conquest of Ireland (perhaps) (pp. 94-324). New York: Lynch, Cole and Meehan.

Mitchel, J. (1899). The history of Ireland from the treaty of Limerick to the present time: being a continuation of the history of the Abbé MacGeoghegan (Vols. I and II). Glasgow: Cameron and Ferguson.

Mitchel, J. (1917). An Ulsterman for Ireland. Being letters to the Protestant farmers, labourers and artisans of the North of Ireland [.], with a foreword by Eoin MacNeill. Dublin: Candle Press.

Mitchel, J. (1945 [1867]). Mitchel on Meagher. In: M. J. MacManus (Ed.), Thomas Davis and Young Ireland (pp. 71-105). Dublin: Stationery Office.

Mitchel, J. (1996). Jail journal 1876. Poole: Woodstock Books/Cassell.

Mokyr, J. (1980). The deadly fungus: an econometric investigation into the short-term demographic impact of the Irish Famine, 1846-1851. Research in Population Economics, 2, 237-277.

Molony, J. N. (1995). A soul came into Ireland: Thomas Davis 1814-1845, a biography. Dublin: Geography Publications.

Morash, C. (1995). Writing the Irish Famine. Oxford: Clarendon Press.

Nairn, T. (1997 [1993]). Demonising nationality. In: T. Nairn, Faces of Nationalism: Janus Revisited (pp. 57-67). London: Verso.

Nash, C. (1993). 'Embodying the nation': the West of Ireland landscape and Irish identity. In: B. O'Connor \& M. Cronin (Eds.), Tourism in Ireland: a critical analysis (pp. 86-112). Cork: Cork University Press. 
Nash, C. (1998). Visionary geographies: designs for developing Ireland. History Workshop Journal, 45, 49-78.

Newman, D. P., \& Paasi, A. (1998). Fences and neighbours in the postmodern world: boundary narratives in political geography. Progress in Human Geography, 22, 186-207.

Newsinger, J. (1980). John Mitchel and Irish nationalism. Literature and History, 6, 182-200.

Ó Cathaoir, B. (1978). John Mitchel. Dublin: Clódhanna Teoranta.

O’Conner, R. (1985). Jenny Mitchel: Young Irelander, a biography. Dublin: O’Conner Trust.

O'Farrell, P. (1982). Whose reality? The Irish Famine in history and literature. Historical Studies, 20, $1-13$.

Ó Gráda, C. (1989). The Great Irish Famine. London: Macmillan.

Ó Gráda, C. (1993). Ireland before and after the Famine: explorations in economic history, 1800-1925 (2nd ed). Manchester: Manchester University Press.

Ó Gráda, C. (1999). Black'47 and beyond: the great Irish famine in history, economy, and memory. Princeton NJ: Princeton University Press.

O'Hegarty, P. S. (1917). John Mitchel: an appreciation, with some account of Young Ireland. Dublin: Maunsel.

O’Neill, M. (1945). John Mitchel. In: M. J. MacManus (Ed.), Thomas Davis and Young Ireland (pp. 43 45). Dublin: Stationery Office.

Pearse, P. (1976a [1916]). The sovereign people. In: P. Pearse, The murder machine, and other essays (pp. 78-96). Dublin: Mercier Press.

Pearse, P. (1976b [1916]). Ghosts. In: P. Pearse, The murder machine, and other essays (pp. 28-44). Dublin: Mercier Press.

Penrose, J. (1994). 'Mon pays ce n'est pas un pays' Full Stop: the concept of nation as a challenge to the nationalist aspirations of the Parti Québécois. Political Geography, 13, 161-181.

Penrose, J. (2001). Nationalism versus democracy? The treatment of minority groups and state legitimacy, paper given at the Annual Meeting of the Association of American Geographers, New York.

Poole, M. A. (1997). In search of ethnicity in Ireland. In: B. Graham (Ed.), In search of Ireland (pp. 128-147). London: Routledge.

Power, P. F. (1996). Revisionist nationalism's consolidation, republicanism's marginalization, and the peace process. Éire-Ireland, 31, 89-122.

Sebestyen, A. (1986). Prison letters of Countess Markievicz. London: Virago.

Shannon-Mangan, E. (1996). James Clarence Mangan: a biography. Blackrock, Co. Dublin: Irish Academic Press.

Shaw, D. J. B. (1998). 'The chickens of Versailles': the new Central and Eastern Europe. In: B. Graham (Ed.), Modern Europe: place, culture and identity (pp. 121-142). London: Arnold.

Smith, A. D. (1986). The ethnic origin of nations. Oxford: Basil Blackwell.

Smith, A. D. W., \& Williams, C. H. (1983). The national construction of social space. Progress in Human Geography, 7, 502-518.

Thom's Irish Almanac and official directory with the Post Office Dublin city and County Directory for the year 1853. Dublin: Alexander Thom.

Walker, B. (1996). 1641, 1689, 1699 and all that: the Unionist sense of history. In: B. Walker, Dancing to history's tune: history, myth and politics in Ireland. Institute of Irish Studies, Belfast.

Waterman, S. (1998). Political Geography as a mirror of political geography. Political Geography, 17, 373-388

Woodham-Smith, C. (1962). The Great Hunger: Ireland 1845-9. London: Hamish Hamilton.

Yeats, W. B. (1970 [1914]). Thomas Davis: speech at the Davis centenary. In: R. McHugh (Ed.), Davis. Mangan, Ferguson? Tradition and the Irish writer. Writings by W. B. Yeats and by Thomas Kinsella (pp. 15-20). Dublin: Dolmen Press

Yeats, W. B. (1990 [1939]). Under Ben Bulben. In: D. Albright (Ed.), W. B. Yeats: the poems (pp. $373-$ 376). London: J. M. Dent. 